\title{
Embedding reflection on graduate attributes in the psychology curriculum: The impact on self-efficacy and the perceived value of graduate attributes.
}

\author{
Maxine V. Swingler * \\ School of Psychology \\ University of Glasgow, UK \\ Maxine.swingler@glasgow.ac.uk \\ Gillian Hendry \\ School of Education and Social Sciences, \\ University of the West of Scotland, UK \\ Gillian.Hendry@uws.ac.uk
}

\section{Abstract}

Psychology graduates face a volatile job market: promotion of their skills is increasingly important, yet they often lack awareness of and engagement with their Graduate Attributes (GAs); the employability skills developed throughout university to prepare them for the world of work. To address this, we designed, implemented, and evaluated a GA reflective activity in a UK university. Undergraduate psychology students completed a measure of their self-efficacy in GAs (GASE) before and after taking part in a GA reflective activity. Students were asked to provide qualitative feedback on the value of the activity. GASE was higher after the activity but this effect was relatively small. Thematic analysis indicated that the activity was valued, but students wanted clearer guidance on the development and application of GAs. In summary the GA activity had a marginal impact on GA self-efficacy and appeared to raise awareness of GAs and career goals. This reflective activity can be embedded in the curriculum as a stand-alone workshop or as part of personal development planning. Further work is needed to support students in identifying opportunities for skill development.

${ }^{*}$ Corresponding Author 
Keywords: Graduate Attributes, Employability, Self-Efficacy, Psychology, Personal Development Planning.

\section{Introduction}

\section{Definitions and aim of the paper}

Generic graduate attributes are defined as "the qualities, skills, and understanding a university community agrees its students should develop during their time within the institution" (Bowden et al., 2000; cited in Barrie, 2006, p. 217). There is increasing emphasis on the importance of making Graduate attributes (GAs) more explicit to students as part of their degree programme, and the role of students themselves in proactively developing GAs (Higher Education Academy [HEA], 2015). A psychology degree embeds training in generic skills such as communication, critical thinking and teamwork,providing an excellent foundation to support entry into a range of careers (Quality Assurance Agency [QAA], 2019), yet undergraduate students are often unaware of the importance of these skills (Morris et al., 2013) or even that they are doing them, and can be reluctant to engage with optional employability activities provided by their Higher Education Institution (HEI; O'Leary, 2016). Given the diverse career routes of psychology graduates (Morrison-Coulthard, 2016), it is essential to provide undergraduate students with opportunities to reflect on and develop their graduate skills in the context of their future career aspirations. The focus of this paper is three-fold. First, to evaluate an intervention aimed at increasing awareness of and engagement with graduate attributes in pre-honours undergraduate psychology students. Second, to investigate self-efficacy in graduate attributes in the context of higher education, and third to explore students' perspectives on graduate attributes and perceived opportunities for development.

\section{Awareness of Graduate Attributes in Psychology}


One of the issues around GAs is that while graduates are highly qualified in their discipline-specific skills, employers report that graduates are inadequately prepared in generic workplace skills such as teamwork, leadership, motivation, problem solving, and communication (Burke \& Hannaford-Simpson, 2019; Heaton et al., 2008; Lowden et al., 2011). HEl's have responded to the requirement placed on them to develop graduate skills by implementing GAs frameworks with a common skill set across institutional frameworks (Artess et al., 2017; Cumming, 2010; Docherty \& Fernandez, 2014; Osmani et al., 2015) which are contextualised within each discipline (O'Leary, 2016) though may vary cross-culturally; for instance, in comparison to the UK, the US has been identified as promoting more personal development and social purpose (O'Connor et al., 2011).

HEls and accreditation bodies have integrated graduate attributes into the curriculum in the form of Personal Development Planning (PDP), capstone modules, partnerships with external organisations and stand-alone careers sessions (Artess et al., 2017; British Psychological Society, 2019; Popovic et al., 2010; Quality Assurance Agency, 2009; Strivens \& Ward, 2010). In the US, there is a focus on the 'ability-based curriculum' (Oliver, 2013), to define, monitor and articulate GAs (Nair et al., 2009). However, increasing demands on academics (Bothwell, 2018) and variable levels of support can make incorporating PDP training into the curriculum challenging (Quinton \& Smallbone, 2008).

\section{Current study}

To address this, we created an opportunity within the psychology curriculum for undergraduates to reflect on their development of GAs. Reflection is central in both teaching and learning, professional practice and employability (Boud, 1999; Rogers, 2001) and develops students' awareness of their own abilities (Moon, 2004). The ability to self-reflect is a facet of psychological literacy (McGovern et al., 2010) and professional practice in psychology (Donati, 2016), but this ability is not always recognised by psychology students (Marsh, 2014). By encouraging reflection on GAs developed through academic and extracurricular activities we aim to increase students' awareness of and exploration of their own abilities so they can focus on development of future skills and confidently express them in recruitment (Yorke \& Knight, 2006). Self- 
reflection also underpins efficacy beliefs about an individuals' future capabilities (Bandura et al., 2001), and previous research has shown that individuals can generalise ability beliefs from previous mastery experiences to similar novel tasks (Gorges \& Göke, 2015). If students draw on relevant mastery experiences in the reflective tasks (e.g., a successful presentation) we would expect an impact on their self-efficacy in relevant abilities (e.g., effective communicator). As such, in our evaluation of the reflective activity students self-assessed their GAs using the GAs self-efficacy scale (GASE); 30 self-efficacy statements applied to the University of Glasgow GAs framework (University of Glasgow, n.d). Self-efficacy is defined as "judgments of capabilities to organize and execute courses of action" (Bandura, 1986, p.391), is known to predict educational and career outcomes (Gore, 2006; Gainor, 2006; Lent \& Brown, 2013) and indicate the impact of an intervention (Bartsch et al., 2012; Finney \& Schraw, 2003).

Proceeding on the basis that reflection on graduate attributes will have a positive impact on self-efficacy, the primary hypothesis predicts an increase in students' GASE after the reflection activity. The secondary hypothesis predicts that this effect will vary for different GASE statements.

Understanding and incorporating students' perspectives on the skills they are acquiring through their studies helps focus development of new approaches and practices (Vanhercke et al., 2014) and increases student engagement with employability skills (Tymon, 2013). To this end we used open text survey questions to explore' students' perspectives on the value of GAs and their experience of the GA reflection activity.

\section{Method}

\section{Participants}

106 second year psychology students (80 female, 26 male) aged between 18 and 46 (M $=20.5)$ participated in the reflection activity and evaluation. Students were recruited in 
their practical lab sessions and participation was voluntary. Sample size was based on a minimum sample size for a one tailed hypothesis as 51 and maximum 102 with an anticipated statistical power of .8, effect size of .5 and probability level of .05 (Cohen, 1988; Soper, n.d). In addition, 164 second year psychology students, (113 female, 42 male, 9 did not disclose their sex) participated in a short survey consisting of 3 open ended questions to evaluate the value of the activity. Of those who disclosed it $(n=155)$, age ranged from 18 to $46(M=20.32)$.

\section{Materials and Procedure}

The graduate attributes reflection task materials are included in Appendix A. The materials consisted of self-assessment questions that asked participants to identify examples of development each of the 10 GAs (using the University of Glasgow Graduate Attributes Framework) from their personal experience, identify how GAs were relevant in a job application, and specific GAs they would like to develop further.

The graduate attributes self-efficacy measure (GASE) is included in Appendix B. GASE is a measure of student self-efficacy beliefs based on the University of Glasgow Graduate Attributes Framework and was developed by the authors. Each of the 10 graduate attributes statements across 3 dimensions were developed into 30 questionnaire items with a four point Likert scale. The questionnaire was piloted with 16 Psychology students who confirmed that the questions were clear and had no suggestions for changes.

The study was approved by the College of Science and Engineering Ethics committee at the University of Glasgow. Students participated as part of a practical class in applied psychology. Before the graduate attributes reflection task, participants completed the GASE (time 1) at the start of the class using pen and paper. Students discussed the GAs reflection activity in groups and then completed all questions individually within class time. The following week, participants completed the GASE at the start of the class (time 2).

Approximately four weeks after the GAs reflection task, students were asked the following questions in a qualitative survey: 
Q1: Please tell us what you enjoyed about your sessions on graduate attributes Q2: Is there anything we should adapt or change about this session? Q3: Why are graduate attributes important to you?

Braun and Clarke's (2019) reflexive thematic analysis was applied to the data, conducted by three independent analysts to increase quality and rigour of the findings (Yardley, 2007).

\section{Results}

\section{Graduate Attribute Self-Efficacy (GASE)}

Responses from time 1 and time 2 were matched across participants using an anonymous identifier. Data from 7 participants was removed using listwise deletion due to missing responses $(N=99)$. To summarise individual participants' scores all 30 items of the GASE questionnaire responses were summed to provide one composite GA score per participant at time 1 and one composite score at time 2. Results of Cronbach's alpha tests of reliability on 30 items indicated high reliability for the GASE questionnaire at time $1(\alpha=.91)$ and time $2(\alpha=.91)$.

All statistical tests were implemented using IBM SPSS (Version 25). A paired samples ttest (one tailed) ${ }^{1}$ compared composite GASE scores at time 1 [M = 92.2, SD =10.7] and composite GASE scores at Time $2[\mathrm{M}=94.5, \mathrm{SD}=10.1]$ and found higher composite GASE at time 2, $(t(98)=-2.69, \mathrm{p}=.008, d=.27), 95 \% \mathrm{Cl}[-3.89,-.59]$, indicating a small effect size (Cohen, 1988). To investigate the impact of the reflective activity on specific GASE items, a Wilcoxon Signed Ranks test ${ }^{2}$ (one tailed) compared GASE on each of the 30 items at time 1 and time 2. The descriptive statistics and results are reported in Table 1. After application of a Bonferroni correction for multiple comparisons $(\mathrm{p}<.002)$, GASE was higher at time 2 for items 10 ( / feel confident in my ability to work 
independently on scientific projects) and 13 (I can articulate complex ideas to diverse audiences) with small to medium effect sizes (Rosenthal, 1991). 
Table 1 Descriptive statistics and the results of Wilcoxon Signed Ranks tests comparing self-efficacy scores for each GASE questionnaire item at time 1 and time 2.

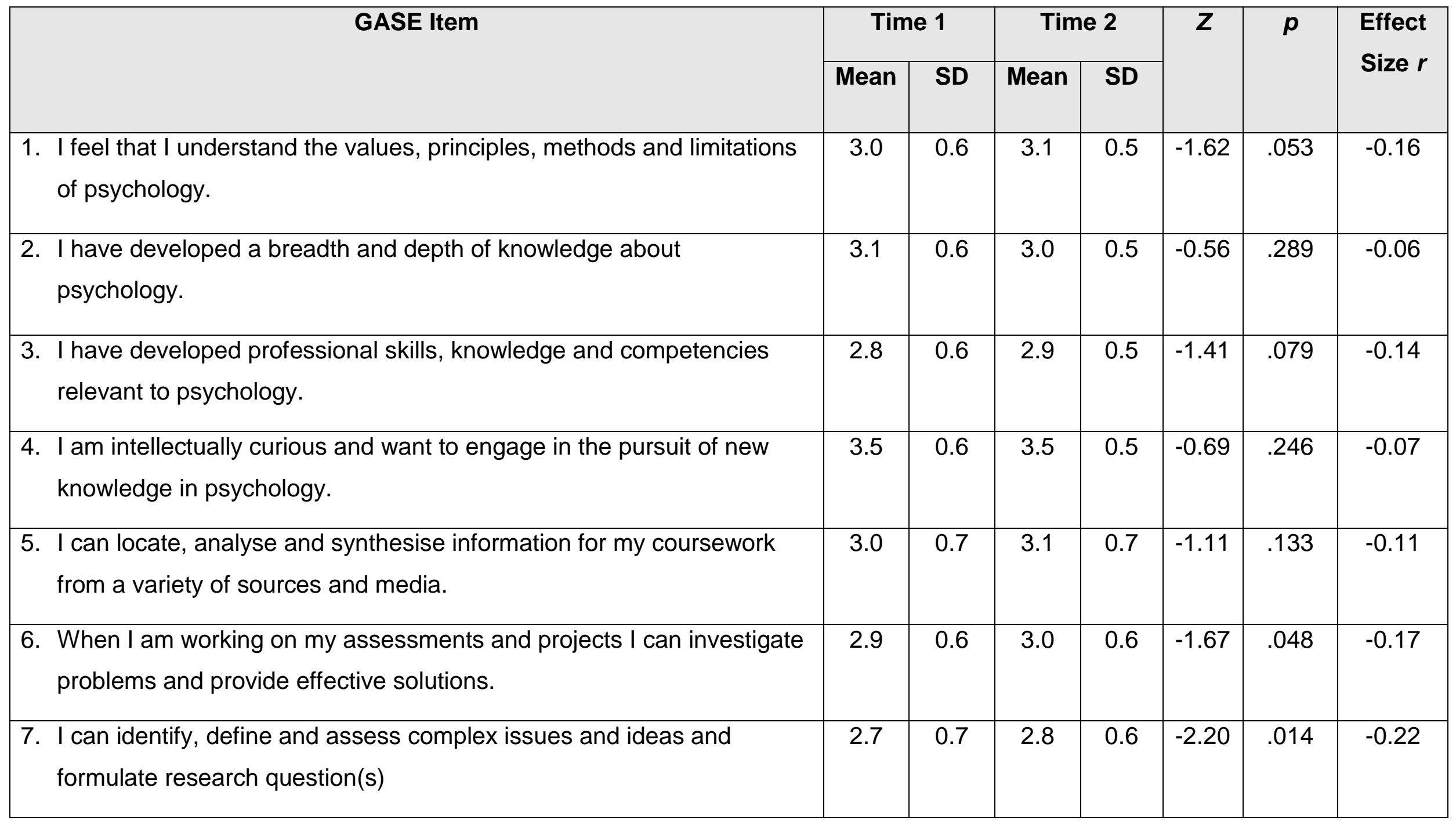




\begin{tabular}{|c|c|c|c|c|c|c|c|}
\hline 8. I feel I can critically evaluate new psychological information & 2.8 & 0.7 & 2.9 & 0.7 & -1.05 & .146 & -0.11 \\
\hline $\begin{array}{l}\text { 10.I feel confident in my ability to work independently on scientific } \\
\text { projects. }\end{array}$ & 2.8 & 0.7 & 3.0 & 0.7 & -3.12 & $.001^{*}$ & -0.31 \\
\hline $\begin{array}{l}\text { 12. I can manage my own performance to meet expectations and } \\
\text { demonstrate drive, determination, and accountability in my studies. }\end{array}$ & 3.1 & 0.6 & 3.0 & 0.7 & -0.31 & .379 & -0.03 \\
\hline 13. I can articulate complex ideas to diverse audiences. & 2.7 & 0.7 & 2.9 & 0.7 & -3.02 & $.001^{*}$ & -0.30 \\
\hline $\begin{array}{l}\text { 15. I can communicate clearly and confidently, and listen and negotiate } \\
\text { effectively with others. }\end{array}$ & 3.2 & 0.7 & 3.2 & 0.7 & 0.00 & .500 & 0.00 \\
\hline $\begin{array}{l}\text { 16. I feel I can confidently explain and challenge psychological concepts } \\
\text { and theories }\end{array}$ & 2.7 & 0.7 & 2.8 & 0.6 & -2.23 & .013 & -0.22 \\
\hline $\begin{array}{l}\text { 17.I feel I can confidently communicate my psychological knowledge to } \\
\text { anyone }\end{array}$ & 2.9 & 0.7 & 2.9 & 0.7 & -0.26 & .399 & -0.03 \\
\hline
\end{tabular}




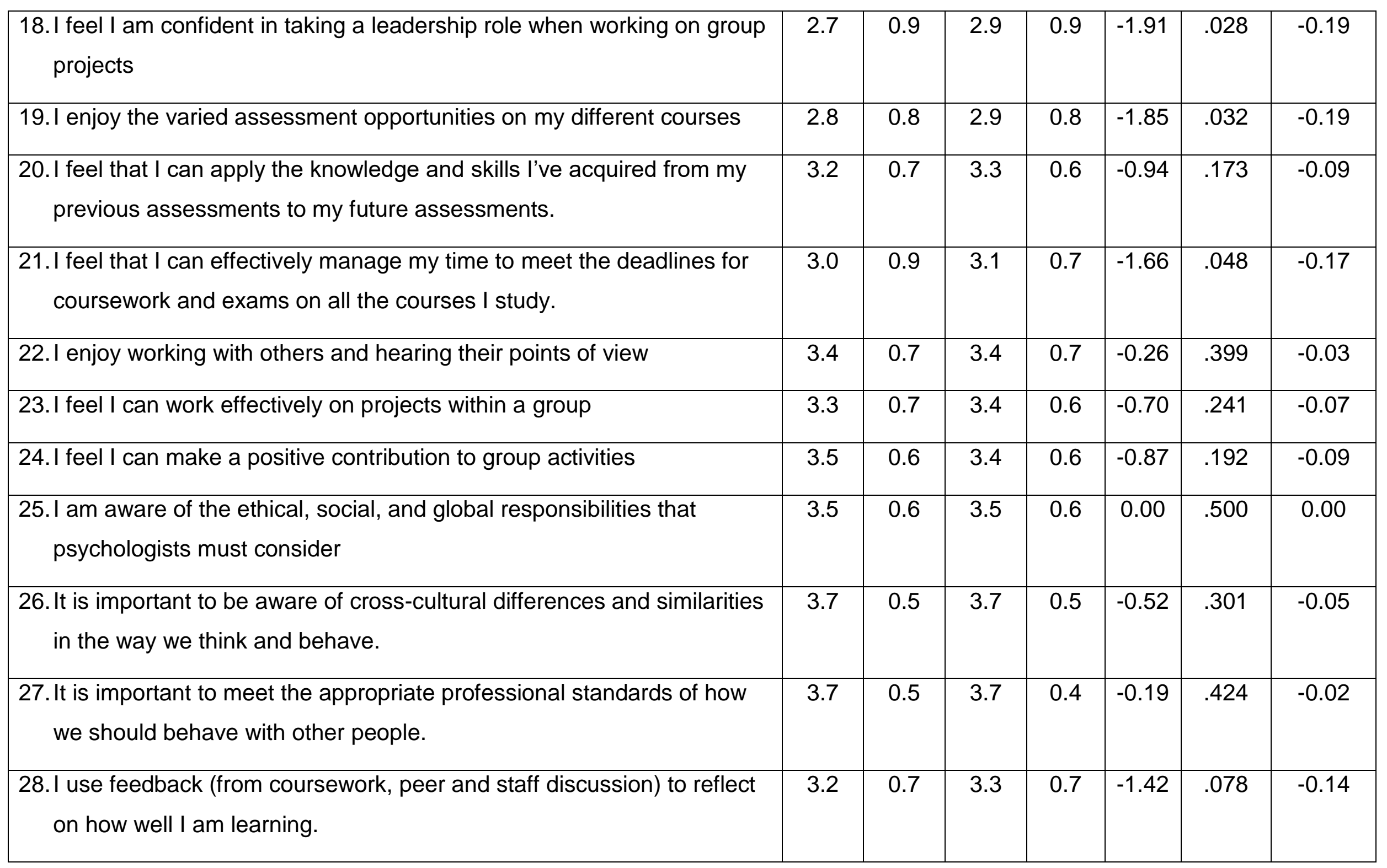




\begin{tabular}{|c|c|c|c|c|c|c|c|}
\hline $\begin{array}{l}\text { 29. I set myself goals on how I wish to develop as a person, e.g. in reflect } \\
\text { of skills/knowledge, moving closer towards a future career. }\end{array}$ & 3.1 & 0.7 & 3.1 & 0.7 & -0.10 & .460 & -0.01 \\
\hline $\begin{array}{l}\text { 30. I am aware of the skills and knowledge I have developed whilst } \\
\text { becoming a student }\end{array}$ & 3.2 & 0.6 & 3.2 & 0.6 & -0.55 & .292 & -0.06 \\
\hline
\end{tabular}

Note. Each item is associated with one of the GAs in the GAs matrix, see Appendix B for details. Z indicates the test statistic converted to a Z score. * indicates that the difference was significant at the $<.002$ level after Bonferroni correction. The effect size is indicated by the $r$ value (Rosenthal, 1991), based on a sample size of 99 . 


\section{Qualitative Survey}

Analysis of responses to the three qualitative survey questions identified the following themes, demonstrated with illustrative quotes (only the most pertinent detailed for brevity) in tables 2,3 , and 4 below.

Table 2. Themes identified and example quotes received in answer to Q1: Please tell us what you enjoyed about your sessions on graduate attributes

\begin{tabular}{|l|l|}
\hline Theme & Example quotes \\
\hline $\begin{array}{l}\text { Recognising the value of } \\
\text { graduate attributes }\end{array}$ & $\begin{array}{l}\text { "It was good to think about the attributes... and } \\
\text { how these apply in the working world" } \\
\text { "Being reminded of the graduate attributes was } \\
\text { good, as well as thinking of examples for each will } \\
\text { help us when constructing a CV" }\end{array}$ \\
\hline Thinking to the future & $\begin{array}{l}\text { "Made me think of my future career" } \\
\text { "It forces me to think about the future" } \\
\text { reflection }\end{array}$ \\
\hline $\begin{array}{l}\text { "Gave me insight into different skills I developed } \\
\text { but didn't recognise" } \\
\text { "Made me take a step back and view myself as } \\
\text { having different skills which was good" }\end{array}$ \\
\hline
\end{tabular}

Students valued the sessions for several reasons. They recognised the explicit outcomes associated with learning about graduate attributes - their application in the 'real' world and their use in developing CVs and placed value on graduate attributes as a tool for both looking to the future and reflecting on the past: thinking about where they want to head in their careers, but also about what they have already achieved. 
Table 3. Themes identified and example quotes received in answer to Q2: Is there anything we should adapt or change about this session?

\begin{tabular}{|l|l|}
\hline Theme & Example quotes \\
\hline More real-world experience & $\begin{array}{l}\text { "Experiences are needed... what kind of } \\
\text { experience is appropriate?" } \\
\text { "Provide workshops that can help } \\
\text { undergraduates to engage in 'real world' } \\
\text { situations" }\end{array}$ \\
\hline $\begin{array}{l}\text { More learning about graduate } \\
\text { attributes: }\end{array}$ & $\begin{array}{l}\text { "I do not feel any more confident in what they } \\
\text { are" } \\
\text { "Graduate attributes still feel quite separated } \\
\text { from the rest of the academic experience" }\end{array}$ \\
\hline
\end{tabular}

The clearest suggestions for change revolved around gaining more real world experience and more learning about what graduate attributes are: students want to see application to situations that they are likely to encounter where they can use their graduate attributes, and be confident in knowing what they are and how they can support and are supported by other facets of the academic experience.

Table 4. Themes identified and example quotes received in answer to Q3: Why are graduate attributes important to you?

\begin{tabular}{|l|l|}
\hline Theme & Example quotes \\
\hline For self-development & $\begin{array}{l}\text { "They make me a more well-rounded individual } \\
\text { which will help in pursuing a career and in life } \\
\text { generally" } \\
\text { "It makes me more aware of my strengths and } \\
\text { weaknesses" }\end{array}$ \\
\hline For goal achievement & $\begin{array}{l}\text { "We need them to reach goals" } \\
\text { "They provide definitions for goals outside } \\
\text { academic requirements" }\end{array}$ \\
\hline For employability & $\begin{array}{l}\text { "They improve employability" } \\
\text { "I want a career in psychology" }\end{array}$ \\
\hline
\end{tabular}

Students recognised that graduate attributes can be used as a tool not restricted to the educational environment but in wider terms too; highlighting the transferability of these 
skills. They detailed that graduate attributes are important in terms of self-development, achieving goals, and are fundamental for future career prospects; highlighting that they are not only worth engaging with whilst still studying, but also for the longer term.

\section{Discussion}

The quantitative findings suggest that students can improve their self-efficacy by reflecting on how academic, extra-curricular and personal experience can develop their graduate attributes. These findings support previous work reporting that reflection on skill development can positively impact students' awareness of GAs and employability (Yorke \& Knight, 2006; Morris et al., 2013; Reddy et al., 2013). One explanation for the current findings is that the reflective activity prompted students to evidence their skills and draw on enactive mastery experiences, an important source of self-efficacy (Gorges \& Göke, 2015). Higher levels of self-efficacy in specific GAs such as communication of complex ideas could be explained by communication skills being central in psychology curricula and psychological literacy (Hulme, 2014; QAA, 2019), providing many mastery experiences (e.g., reports, essays, oral presentations) to draw on. The increase in selfefficacy in the ability to work independently on scientific projects could reflect students' recognition of importance of research skills training in the undergraduate degree (Morris et al., 2013; QAA, 2019).

\section{The student perspective on GAs}

The qualitative feedback provided further insight into student perspectives on GAs.

Firstly, students recognised the value of GAs in terms of encouraging self-development, facilitating self-reflection, and contributing to goals: as noted by previous work (e.g. Belwal et al., 2017; Clarke, 2018; Hill et al., 2016), and that can be considered as markers of student success (Higher Education Academy, 2018). Students also valued GAs in terms of enabling future employment opportunities (e.g. Bridgstock, 2009) and creating a wider awareness of skills (Bath et al., 2004). The mean scores of twenty- 
seven out of the thirty items on the GASE either stayed the same or increased; indicating that when being made to pointedly think about their GAs, students were recognising the skills they had, how they contribute to their perceived self-efficacy, and why they were important.

However, students also recognised that more could be done to embed the learning about and experience of GAs in the curriculum (e.g., Bond et al., 2017; Swingler et al., 2019). Research has documented the importance of providing students with GA development opportunities in terms of both academic and extra-curricular activities (e.g. Manathunga et al., 2009), highlighting the value of curricula being designed to include experiences (Nicol, 2010). This may provide an explanation as to why only two items in the GASE showed a significant increase in scores between times 1 and 2; it could be that students felt that the activity they undertook particularly related to items 10 (/ feel confident in my ability to work independently on scientific projects) and 13 (I can articulate complex ideas to diverse audiences), in which case, if there were more continual embedding of GAs in the curriculum, students should more easily be able to identify GA development experiences. Such embedding of real-life work experience has shown to have a positive impact on students' psychological literacy (Barton et al., 2019; Mair et al., 2013; Moores \& Reddy, 2012; Reddy et al., 2013), so it is vital that students have opportunities to demonstrate GAs as opposed to discussing them abstractly.

\section{Practical Implications}

The reflective activity has been adapted for large classes in different disciplines successfully (Barr \& Rolinska, 2018), and can be used as a one-off activity or as part of a PDP portfolio. To further develop self -efficacy beliefs and their self-regulatory strategies students need to set moderately challenging goals that require them to achieve more than they did previously (Cheng et al., 2015), creating record of skills development in the context of career aspirations (Margolis \& McCabe, 2006; QAA, 2009; Strivens \& Ward, 2010). Subsequent versions of the GAs reflection activity have incorporated goal setting and reflection on skills development, whereby students link 
GAs to their career goals and reflect on their work experience (Swingler et al., 2018, 2019).

\section{Limitations and future research}

The small effect size and the finding that only 2 of the 30 GASE items were significantly improved limit the application of these findings. All students participated in the intervention without a control comparison group to compare with, thus, repeated exposure to the GASE measure itself could provide an alternative explanation for the differences at time points 1 and 2 . This issue is common in studies of the effectiveness of PDP using naturally occurring data as with-holding an intervention from students raises ethical concerns (Strivens \& Ward, 2010). In addition, the validity of single and multi-item measures of skills and attributes is debatable, and in practice, GAs are not distinct and often overlap (Oliver, 2013). Further work on the underlying constructs of graduate attributes (Lipan, 2019; Osmani et al., 2015) and psychological literacy (Roberts et al., 2015) would shed light on how to effectively evaluate interventions in terms of self-efficacy. Finally, awareness of GAs can increase with years of study and for students specialising in psychology (Morris et al., 2013). Future research investigating GASE across years of study would help establish how PDP interventions contribute to students' self-efficacy in their transition through higher education (Lent \& Brown, 2013; QAA, 2018).

\section{Conclusion}

The present findings suggest that a short reflective activity can impact self-efficacy in graduate attributes and can be applied in the context of career goals and PDP to help improve the work-readiness of psychology undergraduates. While students recognise the value of developing their GAs, they do not necessarily recognise opportunities in which to do so: they know it is important, but do not know how to do it. As such, educators need to be more explicit in terms of the specific skills that are being developed in every learning situation and help students to recognise GA development opportunities outside the confines of the classroom. If this can be achieved, students 
may be more able to identify with being a psychology graduate, the skills that that entails, and the opportunities it affords in whatever they go on to do next.

\section{Acknowledgements}

Thank you to Drs Jason Bohan and Heather Cleland-Woods who helped to facilitate and evaluate the GAs reflection activity and to Dr Archie Roy for providing advice on employability. Thank you to Dr Nicola Greenlaw who provided statistical advice and to Nayab Ahmad and Emma Gilmour who reviewed the qualitative analysis.

\section{Author notes}

The project materials and raw data used in this manuscript are openly available via https://osf.io/yzp75/ No aspects of this study were pre-registered.

Maxine V. Swingler ORCID ID https://orcid.org/0000-0002-0108-0212

Gillian Hendry ORCID ID http://orcid.org//0000-0001-9440-6316

\section{Data notes}

1. Composite GASE scores at Time 1 and Time 2 were normally distributed and met the assumptions for parametric tests.

2. Data was 4 point Likert scale data and not normally distributed, so non-parametric tests were deemed appropriate.

\section{References}

Artess, J., Hooley, T., \& Mellors-Bourne, R. (2017). Employability: A Review of the

Literature 2012-2016. Higher Education Academy. https://www.advance-he.ac.uk/knowledgehub/employability-review-literature-2012-2016 
Bandura, A. (1986). Social foundations of thought and action: A social cognitive theory.

Prentice Hall.

Bandura, A., Barbaranelli, C., Vittorio, C., Pastorelli, C. (2001). Self-efficacy beliefs as shapers of children's aspirations and career trajectories. Child Development, 72, 187-206.

Barr, M. \& Rolinska, A. (2018). Reflective class exercises case study. University of Glasgow. https://www.gla.ac.uk/myglasgow/leads/goodpractice/graduateattributes/cs_mb/

Barrie, S. C. (2006). Understanding what we mean by the generic attributes of graduates. Higher Education, 51(2), 215-241. https://doi.org/10.1007/s10734-004-6384-7

Barton, E., Bates, E. \& O’Donovan, R. (2019). 'That extra sparkle': students' experiences of volunteering and the impact on satisfaction and employability in higher education. Journal of Further and Higher Education, 43(4), 453-466. https://doi.org/10.1080/0309877X.2017.1365827

Bartsch, R.A., Casee, K.A. \& Meerman, H. (2012). Increasing academic self-efficacy in statistics with a live vicarious experience presentation. Teaching of Psychology, 39(2), 133-136. https://doi.org/10.1177/0098628312437699

Bath, D., Smith, C., Stein, S. \& Swann, R. (2004). Beyond mapping and embedding graduate attributes: bringing together quality assurance and action learning to create a validated and living curriculum. Higher Education Research \& Development, 23(3), 313-328. https://doi.org/10.1080/0729436042000235427

Belwal, R., Priyadarshi, P. \& Al Fazari, M.H. (2017). Graduate attributes and employability skills: graduates' perspectives on employers' expectations in Oman. International Journal of Educational Management, 31(6), 814-827. https://doi.org/10.1108/JJEM-05-2016-0122

Bond, C.H., Spronken-Smith, R., McLean, A., Smith, N., Frielick, S., Jenkins, M. \& Marshall, S. (2017). A framework for enabling graduate outcomes in undergraduate programmes. Higher Education Research \& Development, 36(1), 43-58.

Bothwell, E. (2018). Work-life balance survey 2018: long hours take their toll on academics. Times Higher Education. https://www.timeshighereducation.com/features/work-life-balance-survey- 2018 long-hours-take-their-toll-academics\#survey-answer

Boud, D. (1999). Avoiding the traps: seeking good practice in the use of self-assessment and reflection in professional courses. Social Work Education, 18, 121-132. https://doi.org/10.1080/02615479911220131

Bowden, J., Hart, G., King, B., Trigwell, K. \& Watts, O. (2000). Generic Capabilities of ATN University Graduates. http:/www.clt.uts.edu.au/ATN.grad.cap.project.index.html

Braun V. \& Clarke V. (2019). Reflecting on reflective thematic analysis. Qualitative Research in Sport, Exercise and Health, 11(4), 589-597. http://doi.org/10.1080/2159676X.2019.1628806 
Bridgstock, R. (2009). The graduate attributes we've overlooked: enhancing graduate employability through career management skills. Higher Education Research \& Development, 28(1), 31-44. https://doi.org/10.1080/07294360802444347

British Psychological Society (2019). Standards for the accreditation of undergraduate, conversion and integrated Masters programmes in psychology.

https://www.bps.org.uk/sites/www.bps.org.uk/files/Accreditation/Undergraduate\%20Accreditation \%20Handbook\%202019.pdf

Burke, C. \& Hannaford-Simpson, S. (2019). Investing in your future: the role of capitals in graduate employment pathways. In C. Burke and F. Christie (Eds.) Graduate Careers in Context: Research, policy and practice. Routledge Research in Higher Education. https://doi.org/10.4324/9780203732281

Cheng, M., Pringle Barnes, G., Edwards, C., \& Valyrakis, M. (2015). Transition Skills and Strategies:Selfefficacy. QAA Scotland. https://www.enhancementthemes.ac.uk/docs/ethemes/studenttransitions/self-efficacy.pdf

Clarke, M. (2018). Rethinking graduate employability: the role of capital, individual attributes and context. Studies in Higher Education, 43(11), 1923-1937. https://doi.org/10.1080/03075079.2017.1294152

Cohen, J. (1988). Statistical Power Analysis for the Behavioral Sciences (2nd Edition). Lawrence Earlbaum Associates.

Cumming, J. (2010). Contextualised performance: reframing the skills debate in research education. Studies in Higher Education, 35(4), 405-419. https://doi.org/10.1080/03075070903082342

Docherty, D., \& Fernandez, R. (2014). Career portfolios and the labour market for graduates and postgraduates in the UK. National Centre for Universities and Business. http://www.ncub.co.uk/reports/career-portfolios.html.

Donati, M. (2016). Becoming a reflective practitioner. In B. Douglas (Ed.), The handbook of counselling psychology (4th $\mathrm{Ed})$. Sage.

Finney, S. J. \& Schraw, G. (2003). Self-efficacy beliefs in college statistics courses. Contemporary Educational Psychology, 28(2), 161-186. https://doi.org/10.1016/S0361-476X(02)00015-2

Gainor, K. A. (2006). Twenty-Five Years of Self-Efficacy in Career Assessment and Practice. Journal of Career Assessment, 14(1), 161-178. https://doi.org/10.1177/1069072705282435

Gore, P. A. (2006). Academic Self-Efficacy as a Predictor of College Outcomes: Two Incremental Validity Studies. Journal of Career Assessment, 14(1), 92-115. https://doi.org/10.1177/1069072705281367

Gorges, J. \& Göke, T. (2015). How do I know what I can do? Anticipating expectancy of success regarding novel academic tasks. British Journal of Educational Psychology, 85(1), 75-90. https://doi.org/10.1111/bjep.12064 
Heaton, N., McCracken, M. \& Harrison, J. (2008). Graduate recruitment and development: Sector influence on a local market/regional economy. Education and Training, 50(4), 276-288. https://doi.org/10.1108/00400910810880524

Higher Education Academy. (2015). Framework for embedding employability in higher education. https://www.heacademy.ac.uk/system/files/downloads/embeddingemployability-in-he.pdf

Higher Education Academy. (2018). Developing an integrated institutional approach to student success. https://www.heacademy.ac.uk/knowledge-hub/developing-integrated-institutional-approachstudent-success

Hill, J., Walkington, H. \& France, D. (2016). Graduate attributes: implications for higher education practice and policy. Journal of Geography in Higher Education, 40(2), 155-163. https://doi.org/10.1080/03098265.2016.1154932

Hulme, J. (2014). Psychological literacy - from classroom to real world. The Psychologist, 27, 932-935. https://thepsychologist.bps.org.uk/volume-27/december-2014/psychological-literacy-classroomreal-world

Lent, R. W. \& Brown, S. D. (2013). Social cognitive model of career self-management: Toward a unifying view of adaptive career behavior across the life span. Journal of Counseling Psychology, 60(4), 557-568. https://doi.org/10.1037/a0033446

Lipan, G. (2019, June 5th). Universal Graduate Attributes the 7i Model. QAA Focus on Graduate Skills Sharing Practice event https://www.qaa.ac.uk/scotland/focus-on/graduate-skills\# Lowden, K., Hall, S., Elliot, D. \& Lewin, J.(2011). Employers' perceptions of the employability skills of new graduates. http://www.edge.co.uk/media/63412/employability_skills_as_pdf_-__final_online_version.pdf

Mair, C., Taylor, J. \& Hulme, J. (2013). An introductory guide to psychological literacy and psychologically literate citizenship. Higher Education Academy. https://www.heacademy.ac.uk/sites/default/files/resources/psychological_literacy_and_psychologi cally_literate_citizenship.pdf.

Manathunga, C., Pitt, R. \& Critchley, C. (2009). Graduate attributes development and employment outcomes: tracking PhD graduates. Assessment \& Evaluation in Higher Education, 34(1), 91-103. https://doi.org/10.1080/02602930801955945

Margolis, H., \& McCabe, P. P. (2006). Improving Self-Efficacy and Motivation: What to Do, What to Say. Intervention in School and Clinic, 41(4), 218-227. https://doi.org/10.1177/10534512060410040401

Marsh, C. (2014). 'It's quite weird to write ... you feel like a nut job': The practical and 
emotional consequences of writing personal reflections for assessment in psychology. Reflective Practice, 15(2), 190-202. https://doi.org/10.1080/14623943.2014.883310

McGovern, T. V., Corey, L., Cranney, J., Dixon, W. E., Jr., Holmes, J. D., Kuebli, J. E., Ritchey, K. A., Smith, R. A., \& Walker, S. J. (2010). Psychologically literate citizens. In D. F. Halpern (Ed.), Undergraduate education in psychology: A blueprint for the future of the discipline (p. 9-27). American Psychological Association. https://doi.org/10.1037/12063-001

Moon, J. (2004). Reflection and employability. AdvanceHE.

https://www.advance-he.ac.uk/knowledge-hub/reflection-and-employability

Moores, E. \& Reddy, P. (2012). No regrets? Measuring the career benefits of a

psychology placement year. Assessment and Evaluation in Higher Education, 37(5), 535-554. https://doi.org/10.1080/02602938.2011.553668

Morris, S., Cranney, J., Jeong, J. M., Mellish, L. (2013). Developing psychological literacy: Student perceptions of graduate attributes. Australian Journal of Psychology, 65(1), 54-62. https://doi.org/10.1111/ajpy.12010

Morrison-Coulthard, L. (2016). BPS Careers Destinations (Phase 3) Survey 2016.

British Psychological Society.

https://www.bps.org.uk/sites/bps.org.uk/files/News/News\%20\%20Files/Careers\%20destination\% 20survey.pdf.

Nair, C.S., Patil, A. \& Mertova, P. (2009). Re-engineering graduate skills - a case study. European Journal of Engineering Education, 23(2), 131-139. https://doi.org/10.1080/03043790902829281

Nicol, D. (2010). The foundation for graduate attributes: developing self-regulation through self and peer assessment. The Quality Assurance Agency for Higher Education. https://ewds.strath.ac.uk/REAP/public/Papers/DN The\%20foundation\%20for\%20Graduate\%20At tributes.pdf

O'Connor, K.M., Lynch, K. \& Owen, D. (2011). Student-community engagement and the development of graduate attributes. Education \& Training, 53(2/3), 100-115. https://doi.org/10.1108/00400911111115654.

O'Leary, S. (2016). Graduates' experiences of, and attitudes towards, the inclusion of employability-related support in undergraduate degree programmes; trends and variations by subject discipline and gender. Journal of Education and Work, 30(1), 84105.https://doi.org/10.1080/13639080.2015.1122181

Oliver, B. (2013). Graduate attributes as a focus for institution-wide curriculum renewal: 
innovations and challenges, Higher Education Research \& Development, 32(3), 450-463. https://doi.org/10.1080/07294360.2012.682052

Osmani, M., Weerakkody, V., Hindi, N.M., Al-Esmail, R., Eldabi T., Kapoor, K., \& Irani, Z. (2015). Identifying the trends and impact of graduate attributes on employability: a literature review. Tertiary Education and Management, 21(4), 367-379. https://doi.org/10.1080/13583883.2015.1114139

Popovic, C., Lawton, R., Hill, A., Eland, J. \& Morton (2010). Creating future proof graduates. Higher Education Academy https://www.heacademy.ac.uk/knowledge-hub/creating-future-proof- graduates

Quality Assurance Agency (2009, February). Personal development planning: guidance for institutional policy and practice in higher education. https://www.qaa.ac.uk/docs/qaas/enhancement-and-development/pdp-guidance-for-institutionalpolicy-and-practice.pdf?sfvrsn=4145f581_8

Quality Assurance Agency (2018). Student transitions map. https://www.studenttransitionmap.uk/\#!/guide

Quality Assurance Agency (2019, January). Subject Benchmark Statement: Psychology. https://www.qaa.ac.uk/docs/qaa/subject-benchmark-statements/subject-benchmark-statementpsychology.pdf?sfvrsn=6935c881_13

Quinton, S., \& Smallbone, T. (2008). PDP implementation at English universities: what are the issues? Journal of Further and Higher Education, 32(2), 99-109.

\section{https://doi-org10.1080/03098770701851839}

Reddy, P., Lantz, C. \& Hulme, J. (2013). Employability in Psychology: a guide for departments. Higher Education Academy. https://www.heacademy.ac.uk/system/files/resources/Employability-GuideFinal.pdf

Roberts, L.D., Heritage, B., \& Gasson, N. (2015). The measurement of psychological literacy: a first approximation. Frontiers in Psychology, 6, 105. https://doi.org/10.3389/fpsyg.2015.00105

Rogers, R.R. (2001). Reflection in Higher Education: A Concept Analysis. Innovative Higher Education, 26, 37-57. https://doi.org/10.1023/A:1010986404527

Rosenthal, R. (1991). Meta-analytic procedures for social research. SAGE. 
https://dx.doi.org/10.4135/9781412984997

Soper, D.S. (n.d). A-priori Sample Size Calculator for Student t-Tests [Software]. http://www.danielsoper.com/statcalc

Strivens, J. \& Ward, R. (2010). An overview of the development of Personal

Development Planning (PDP) and e-portfolio practice in UK higher education. Journal of Learning Development in Higher Education Special Edition: Researching PDP Practice. http://journal.aldinhe.ac.uk/index.php/jldhe/article/view/114

Swingler, M.V., Bohan, J., Shilton, S., \& Davies, J. (2018). Succeeding in second year case study. University of Glasgow.

https://www.gla.ac.uk/myglasgow/leads/goodpractice/graduateattributes/cs_ms/

Swingler, M.V., Roy, A.W.N., Rolinska, A. \& Gardani, M. (2019). Focus on graduate skills: students' views on graduate skills. QAA Scotland. https://www.qaa.ac.uk/scotland/focus-on/graduate-skills\#

Tymon, A. (2013). The student perspective on employability. Studies in Higher Education, 38(6), 841-856. https://doi-org/10.1080/03075079.2011.604408

University of Glasgow (n.d). University of Glasgow Graduate Attributes. https://www.gla.ac.uk/media/Media_183776_smxx.pdf

Vanhercke, D.,De Cuyper, N., Peeters, E. \& De Witte, H. (2014). Defining perceived employability: a psychological approach. Personnel Review, 43(4), 592-605. https://doi-org10.1108/PR-07-2012-0110

Yardley, L. (2007). Demonstrating validity in qualitative psychology. In J.A. Smith (Ed.), A practical guide to research methods. Sage.

Yorke, M. \& Knight, P.T. (2006). Embedding Employability into the curriculum. Higher Education Academy. https://www.advance-he.ac.uk/knowledge-hub/embedding-employabilitycurriculum 


\section{Appendix A: Graduate Attributes reflective activity}

University life offers up opportunities to try new things wherever you go: lectures, labs, the library, the sports field, the theatre and the unions: it's almost impossible not to get involved. But thousands of students graduate from Glasgow University each year, so what will make YOUR time here unique? What will you have to show for your time here other than some great memories?

If someone were to ask you what you did at university, you'd probably name the subjects you study. But you're actually learning to do all sorts of other things as well. For example:

- Writing essays develops critical thinking and research skills

- Posters and presentations are great practice in public speaking and communicating your ideas

- Playing for a sports team improves your ability to communicate and work within a team

- Running a club or society requires leadership and motivation, and being ethically and socially aware

With a little thought, you can see that almost everything you can do at university is designed to help you develop useful skills, qualities and abilities - elements of yourself that you might never have discovered had you not come to Glasgow University. We refer to these collectively as our graduate attributes, and they are listed in the table below (or, for easier viewing, at the following web link:

\section{http://www.gla.ac.uk/media/media 183776 en.pdf)}




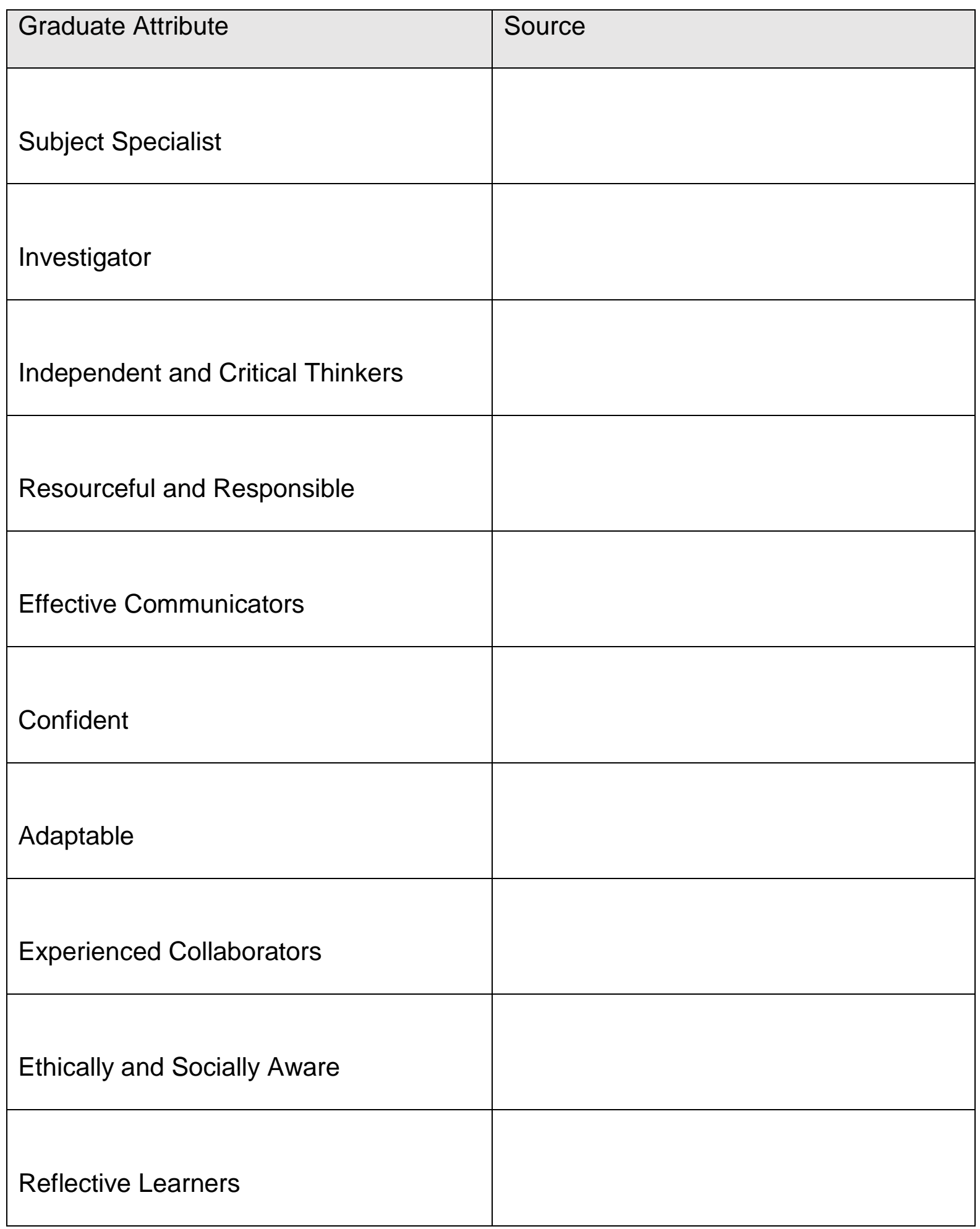


Where have you had the opportunity to develop the Graduate Attributes (GAs) listed above? Think about the Psychology course, your other courses, and your experiences outside of University (jobs, hobbies, volunteering).

\section{Graduate jobs for Psychology Graduates}

Below, you will find descriptions of jobs that Psychology students have gone on to do. Please choose one of these - or make up your own! - and think about what graduate attributes you need to develop in order to make obtaining a job like this more possible.

\section{Clinical Psychologist https://www.prospects.ac.uk/job-profiles/clinical-psychologist}

Educational Psychologist https://www.prospects.ac.uk/job-profiles/educationalpsychologist

Family Support Worker https://www.prospects.ac.uk/job-profiles/family-support-worker

\section{Teacher https://www.prospects.ac.uk/job-profiles/secondary-school-teacher}

Which job did you select?

Which GAs do you think are relevant to this job and why?

If you were to apply for this job, which of the GAs would you try and demonstrate in your application?

If you felt that you wanted to develop a GA further, how would you go about this?

What support/resources would you need to do this?

Useful resources:

https://www.prospects.ac.uk

http://www.gla.ac.uk/services/careers 


\section{Appendix B: Questionnaire Measures}

Graduate Attributes Self-Efficacy

Below are a series of statements related to the $U$ of $G$ graduate attributes framework http://www.gla.ac.uk/students/attributes/ On the basis of your current beliefs in your academic capabilities, personal qualities and transferable skills, please rate your level of agreement with each statement).

1=Strongly Disagree $\quad 2=T e n d$ to Disagree $\quad 3=T e n d$ to Agree $\quad 4=S t r o n g l y$
Agree

\section{Subject specialist}

1. I feel that I understand the values, principles, methods and limitations of psychology.

\begin{tabular}{|c|c|c|c|}
\hline 1 & 2 & 3 & 4 \\
\hline
\end{tabular}

2. I have developed a breadth and depth of knowledge about psychology.

\begin{tabular}{l|l|c|c|}
\hline $\mathbf{1}$ & $\mathbf{2}$ & $\mathbf{3}$ & $\mathbf{4}$ \\
\hline $\begin{array}{l}\text { 3. I have developed professional skills, knowledge and competencies } \\
\text { relevant to psychology. }\end{array}$ \\
\hline $\mathbf{1}$ & $\mathbf{2}$ & $\mathbf{3}$ & $\mathbf{4}$ \\
\hline
\end{tabular}

\section{Investigative}

4. I am intellectually curious and want to engage in the pursuit of new knowledge in psychology.

\begin{tabular}{|c|c|c|c|}
\hline 1 & 2 & 3 & 4 \\
\hline
\end{tabular}

5. I can locate, analyse and synthesise information for my coursework from a variety of sources and media. 


\begin{tabular}{|l|c|c|c|}
\hline $\mathbf{1}$ & $\mathbf{2}$ & $\mathbf{3}$ & $\mathbf{4}$ \\
\hline $\begin{array}{l}\text { 6. When I am working on my assessments and projects I can investigate } \\
\text { problems and provide effective solutions. }\end{array}$ \\
\hline $\mathbf{1}$ & $\mathbf{2}$ & $\mathbf{3}$ & $\mathbf{4}$ \\
\hline
\end{tabular}

\section{Independent and critical thinker}

7. I can identify, define and assess complex issues and ideas and formulate research question(s)

\begin{tabular}{|l|l|l|l}
$\mathbf{1}$ & $\mathbf{2}$ & $\mathbf{3}$ & $\mathbf{4}$
\end{tabular}

8. I feel I can critically evaluate new psychological information 1 2 3 4

9. When faced with problems related to assessments and projects, I can think creatively, imaginatively and innovatively.

1

\section{2}

3
4

\section{Resourceful and responsible}

10. I feel confident in my ability to work independently on scientific projects. 1 2 3 4

11.I feel that am motivated, conscientious and self-sufficient, capable of substantial independent work.

\begin{tabular}{|c|c|c|c|}
\hline 1 & 2 & 3 & 4 \\
\hline
\end{tabular}

12. I can manage my own performance to meet expectations and demonstrate drive, determination, and accountability in my studies.

1

2

3
4 


\section{Effective communicators}

13. I can articulate complex ideas to diverse audiences.

1

2

3

4

14. I can present my ideas clearly and concisely in high quality written and spoken English.

1

15. I can communicate clearly and confidently, and listen and negotiate effectively with others.
1
2
3
4

\section{Confident}

16. I feel I can confidently explain and challenge psychological concepts and theories

1

\begin{tabular}{|c|c|}
\hline 1 & 2 \\
\hline
\end{tabular}

3

4

17.I feel I can confidently communicate my psychological knowledge to anyone.

\begin{tabular}{l|l|l|l}
$\mathbf{1}$ & $\mathbf{2}$ & $\mathbf{3}$ & $\mathbf{4}$
\end{tabular}

18. I feel I am confident in taking a leadership role when working on group projects

1

2

\section{3}

4

\section{Adaptable}

19. I enjoy the varied assessment opportunities on my different courses

1
2
3

4 
20. I feel that I can apply the knowledge and skills I've acquired from my previous assessments to my future assessments.

\begin{tabular}{|c|c|c|c|}
\hline 1 & 2 & 3 & 4 \\
\hline \multicolumn{4}{|c|}{$\begin{array}{l}\text { 21. I feel that I can effectively manage my time to meet the deadlines for } \\
\text { coursework and exams on all the courses I study. }\end{array}$} \\
\hline 1 & 2 & 3 & 4 \\
\hline
\end{tabular}

\section{Experienced Collaborators}

22. I enjoy working with others and hearing their points of view 1 2 3

4

23. I feel I can work effectively on projects within a group

\begin{tabular}{|c|c|c|c|}
\hline $\mathbf{1}$ & $\mathbf{2}$ & $\mathbf{3}$ & $\mathbf{4}$ \\
\hline \multicolumn{2}{|c|}{ 24. I feel I can make a positive contribution to group activities } \\
\hline $\mathbf{1}$ & $\mathbf{2}$ & $\mathbf{3}$ & $\mathbf{4}$ \\
\hline
\end{tabular}

\section{Ethically and Socially Aware}

25. I am aware of the ethical, social, and global responsibilities that psychologists must consider

\begin{tabular}{|l|c|c|}
\hline $\mathbf{1}$ & $\mathbf{2}$ & $\mathbf{4}$ \\
\hline $\begin{array}{l}\text { 26. It is important to be aware of cross-cultural differences and similarities in } \\
\text { the way we think and behave. }\end{array}$ & $\mathbf{3}$ \\
\hline $\mathbf{1}$ & $\mathbf{2}$ & $\mathbf{4}$ \\
\hline $\begin{array}{l}\text { 27. It is important to meet the appropriate professional standards of how we } \\
\text { should behave with other people. }\end{array}$ & $\mathbf{3}$ \\
\hline $\mathbf{1}$ & $\mathbf{2}$ & \\
\hline
\end{tabular}




\section{Reflective Learners}

28.I use feedback (from coursework, peer and staff discussion) to reflect on how well I am learning.

\begin{tabular}{|l|l|l|l}
1 & 2 & 3 & 4
\end{tabular}

29. I set myself goals on how I wish to develop as a person, e.g. in reflect of skills/knowledge, moving closer towards a future career.

\begin{tabular}{|c|c|c|c|}
\hline $\mathbf{1}$ & $\mathbf{2}$ & $\mathbf{3}$ & $\mathbf{4}$ \\
\hline $\begin{array}{l}\text { 30. I am aware of the skills and knowledge I have developed whilst } \\
\text { becoming a student }\end{array}$ \\
\hline $\mathbf{1}$ & $\mathbf{2}$ & $\mathbf{3}$ & $\mathbf{4}$ \\
\hline
\end{tabular}

